\title{
ANALISIS TINGKAT KEPUASAN KONSUMEN TERHADAP PELAYANAN JASA SEWA MOBIL DI RENTAL RESTU KABUPATEN BIAK NUMFOR
}

\author{
Sutrimono \\ Program Studi Administrasi Bisnis, Fakultas Ilmu Administrasi \\ Institut Ilmu Sosial dan Ilmu Politik YAPIS Biak \\ Email : sutrimono@iyb.ac.id
}

\begin{abstract}
Abstrak
Bisnis adalah sekumpulan aktifitas yang dilakukan untuk menciptakan dengan cara mengembangkan dan mentransformasikan berbagai sumber daya menjadi barang atau jasa yang diinginkan konsumen. Penelitian ini bertujuan untuk mengetahui analisis tingkat kepuasan konsumen terhadap pelayanan jasa sewa mobil di Rental Restu Kabupaten Biak Numfor. Teknik pengumpulan data yang digunakan seperti; observasi, wawancara, dan dokumentasi. Metode analisis yang digunakan adalah analisis kualitatif.Hasil penelitian diketahui bahwa Pelayanan terhadap pelanggan di rental restu sangat berpengaruh pada kepuasan pelanggan/konsumen. Berperilaku baik akan menimbulkan kepuasan terhadap pelanggan dan pelaku usaha rental mobil khususnya rental restu, dan dapat membuat penghasilan semakin meningkat (keuntungan yang besar).
\end{abstract}

Kata Kunci: Kepuasan, Konsumen, Pelayanan Jasa.

\section{PENDAHULUAN}

Semakin hari persaingan dalam dunia bisnis sangat ketat terutama di bidang pelayanan dan jasa, hal ini dapat terlihat dari segi kemunculan usaha yang bergerak di bidang jasa, bersamaan dengan hal tersebut banyak pelaku-pelaku bisnis yang mulai tertarik dengan bidang bisnis ini (jasa), khusunya usaha rental mobil. Usaha rental mobil adalah bisnis yang menawarkan jasa penyewaan mobil kepada pihak yang membutuhkan, baik perorangan, maupun perusahaan. Di indonesia rental mobil sudah sangat dikenal oleh masyarakat karena dijadikan sebagai sarana transportasi untuk memenuhi kebutuhan baik liburan, perjalanan bisnis pribadi maupun perusahaan (organisasi). Rental mobil di Indonesia sangat cepat menyebar kesetiap daerah-daerah di Indonesia seperti di Kabupaten Biak Numfor. Bisnis yang bergerak dalam bidang jasa ini sudah banyak bermunculan dimana mana sehingga membuat persaingan semakin lebih ketat. Selain prospek yang bagus, ada beberapa hal yang perlu diperhatikan yaitu perkembangan yang terjadi di dunia bisnis dan industri yang menyebabkan para pelaku usaha sekaligus orang-orang yang terkait dengan kepentingan mereka meningkat mobilitasnya. Sehingga peran serta perusahaan-perusahaan penyewaan mobil menjadi besar artinya, terutama didasari atas kenyataan bahwa, bagi sebagian kelompok orang menggunakan mobil secara menyewa dirasa akan lebih efisien dari pada membeli.

Alat trasportasi merupakan modal dasar untuk mencapai suatu tempat atau tujuan. Tuntutan kegiatan dan aktivitas yang cepat menyebabkan orang harus menggunakan alat transportasi untuk mencapai tujuan. Alat transportasi yang mudah, nyaman, dan paling banyak digunakan salah satunya adalah mobil. 
Melihat kebutuhan masyarakat akan kendaraan, khususnya mobil, maka bisnis rental mobil adalah yang sangat menjanjikan keuntungannya. Karena banyak faktor tertentu yang membuat rental mobil sampai saat ini masih banyak diminati. Bagi sebagian besar masyarakat, keperluan sewa mobil untuk merayakan hari-hari besar keagamaan atau hajatan merupakan syarat utama yang harus dipenuhi, baik itu untuk mudik maupun keperluan lainnya.

Seseorang (pengusaha rental mobil) yang memulai usaha rental mobil di kabupaten Biak Numfor tanpa modal uang, Ia mengatakan memulai usaha rental mobil bukan hanya memiliki modal uang yang cukup banyak tetapi harus juga memiliki modal keberanian sehingga apa yang diinginkan bisa tercapai. Karena jika hanya memiliki modal uang tanpa keberanian tidak akan mengarah kekeberhasilan. Oleh karena itu usaha rental mobil memerlukan pribadi yang memiliki keberanian, kreatif dan yang terpenting adalah menjaga komunikasi yang baik terhadap konsumen sehingga konsumen merasa nyaman dengan pelayanan yang diberikan kepadanya. Terkadang bisnis yang bergerak pada bidang jasa dan pelayanan kurang memperhatikan kepuasan pelanggannya. Sebuah bisnis yang bergerak pada bidang jasa dan pelayanaan harus mengutamakan nilai kepuasan pelanggannya terhadap jasa pelayanan yang telah mereka berikan.

Seperti yang telah dipaparkan sebelumnya, salah satu faktor yang menentukan tingkan keberhasilan dan kualitas pelayanan adalah kemampuan perusahaan dalam memberikan pelayanan komunikasi yang baik kepada pelanggan. Oleh karena itu, keberhasilan perusahaan dalam memberikan pelayanan yang bermutu kepada pelangganya sangat diperlukan karena dengan pendekatan kualitas pelayanan memiliki peran penting bagi strategi perusahaan untuk mempertahankan diri dan mencapai kesuksesan dalam menghadapi persaingan.

Beberapa pemodal sudah menyadari tentang peluang bisnis ini, maka para pemodal mencoba untuk melakukan kerja sama dengan pemilik usaha untuk berinvestasi di bisnis tersebut. Dan juga disamping itu karena bisnis yang bergerak dalam bidang jasa ini cukup menggiurkan maka tidak sedikit pula masyarakat yang mempunyai modal berencana membuka usaha rental mobil sendiri. Sebagai contoh kita lihat kota Biak khususnya di daerah Kampung Baru berdiri sebuah rental mobil yang bernama RENTAL RESTU. Pada awal berdiri rental mobil ini memang tidak begitu mencolok, namun setelah beberapa bulan kedepan RENTAL RESTU ini mampu menyerap banyak pelanggan. Oleh sebab itu RENTAL RESTU mencoba untuk mempertahankan pelanggan barunya tersebut dengan memberikan pelayanan yang baik.

Secara etimologi, bisnis berarti keadaan di mana seseorang atau sekelompok orang sibuk melakukan pekerjaan yang menghasilkan keuntungan. Kata "bisnis" sendiri memiliki tiga penggunaan, tergantung skupnya. Penggunaan singular kata bisnis dapat merujuk pada badan usaha, yaitu kesatuan yuridis (hukum), teknis, dan ekonomis yang bertujuan mencari laba atau keuntungan. Business dictionary menyatakan bisnis adalah organisasi atau sistem ekonomi di mana barang dan jasa dipertukarkan dalam bentuk uang. Bisnis memerlukan investasi yang besar dan pelanggan untuk menjual output pada sejumlah tertentu untuk mendapatkan (menghasilkan) keuntungan. Bukan untuk 
keuntungan pribadi namun bisnis dapat dimiliki secara pribadi. Huat, $T$ Chwee (1990) menyatakan bisnis dalam arti luas adalah istilah umum yang menggambarkan semua aktifitas dan institusi yang memproduksi barang \& jasa dalam kehidupan sehari-hari. Bisnis sebagai suatu sistem yang memproduksi barang dan jasa untuk memuaskan kebutuhan masyarakat (bussinessis then simply a system that produces goods and service to satisfy the needs of our society.

Steinford (1979) menyatakan bisnis ialah suatu lembaga yang menghasilkan barang dan jasa yang dibutuhkan oleh masyarakat. Apabila kebutuhan masyarakat meningkat, maka lembaga bisnis pun akan meningkat pula perkembangannya untuk memenuhi kebutuhan tersebut, sambil memperoleh laba. Griffin dan Ebert (1996) bisnis sebagai aktifitas yang menyediakan barang atau jasa yang diperlukan atau diinginkan oleh konsumen. Dapat dilakukan oleh organisasi perusahaan yang memilki badan hukum, perusahaan yang memiliki badan usaha, maupun perorangan yang tidak memilki badan hukum maupun badan usaha seperti pedagang kaki lima, warung yang tidak memiliki Surat Izin Tempat Usaha (SITU) dan Surat Izin Tempat Usaha (SIUP) serta usaha informal lainnya. Allan Afuah (2004) bisnis adalah suatu kegiatan usaha individu yang terorganisasi untuk menghasilkan dan menjual barang dan jasa guna mendapatkan keuntungan dalam memenuhi kebutuhan masyarakat dan ada dalam industri. Orang yang mengusahakan uang dan waktunya dengan menanggung resiko dalam menjalankan kegiatan bisnis disebut Entrepreneur. los,

Steade dan Lowry

menyatakan bisnis adalah sekumpulan aktifitas yang dilakukan untuk menciptakan dengan cara mengembangkan dan mentransformasikan berbagai sember daya menjadi barang atau jasa yang diinginkan konsumen. Mahmud Machfoed menyatakan bisnis adalah usaha perdagangan yang dilakukan oleh sekelompok orang yang terorganisasi untuk mendapatkan laba dengan memproduksi dan menjual barang atau jasa untuk memenuhi kebutuhan konsumen. Pada dasarnya, definisi "kualitas jasa berfokus pada upaya pemenuhan kebutuhan dan keinginan pelanggan serta ketepatan penyampaiannya untuk mengimbangi harapan pelanggan (Tjiptono, 2000). Wyckof (dalam Lovelock, 1998) dalam Tjiptono, (2000) Kualitas jasa merupakan tingkat kesempurnaan yang diharapkan dan pengendalian atas kesempurnaan tersebut untuk memenuhi keinginan pelanggan.

Disisi lain, definisi dari kualitas jasa yaitu menurut Lupiyoadi (2014) kualitas produk (jasa) adalah sejauh mana produk (jasa) memenuhi spesifikas - spesifikasinya. Menurut ISO9000 dalam Lupiyoadi (2014) Kualitas adalah "degree to which a set of inherent characteristics fulfils requirements" (derajat yang dicapai oleh karakteristik yang inheren dalam memenuhi persyaratan). Persyaratan dalam hal ini adalah: "need or expectation that is stated, generally implied or abligatory" (yaitu, kebutuhan atau harapan yang dinyatakan, biasanya tersirat atau wajib). Jadi, kualitas sebagaimana yang diinterpretasikan ISO 9000 merupakan perpaduan antara sifat dan karakteristik yang menentukan sejauh mana keluaran dapat memenuhi persyaratan kebutuhan pelanggan. 


\section{METODE PENELITIAN}

\section{Lokasi Penelitian}

Penelitian ini dilakukan di Rental

Restu Jln. Sisingamangaraja, Sorido, Kabupaten Biak Numfor.

\section{Jenis Penelitian}

Dalam menentukan jenis penelitian di tempat tersebut agar dapat menghasilakn hasil yang objektif dan representatif dalam penelitian ini, maka peneliti menggunakan metode penelitian kualitatif deskriptif yaitu suatu metode penelitian yang dilakukan secara alamiah sesuai kondisi yang terjadi dilapangan tanpa adanya rekayasa.

\section{Jenis dan Sumber Data}

\section{Jenis Data}

- Data primer : Data penelitian yang diperoleh langsung dari sumber data utama yang meliputi responden atau subyek penelitian dari hasil wawancara dan observasi. Dalam penelitian ini peneliti langsung mengambil data di Rental Restu Kabupaten Biak Numfor.

- Data sekunder : Yang dimaksud dalam penelitian ini adalah data pendukung yang diperoleh dari dokumen atau arsip di Rental Restu Kabupaten Biak Numfor.

\section{Sumber Data}

Penelitian ini dilakukan pada pelanggan yang sedang berada di area Rental Restu yang berlokasi di Jln. Sisingamangaraja, Sorido, Kabupaten Biak Numfor. Untuk menghasilkan data yang relevan maka peneliti mengumpulkan data langsung dari objek yang diteliti, dalam hal ini data diperoleh dari hasil wawancara kepada subyek yang bersangkutan dalam penelitian, subyek penelitian tersebut adalah pelanggan yang ditemui di lokasi penelitian.

\section{Teknik Pengumpulan Data}

Teknik pengumpulan data atau bahan yang relevan, akurat dan terandalkan yang bertujuan untuk menciptakan hasil penelitian yang sesuai dengan tujuan penelitian. Teknik pengumpulan data yang dilakukan dalam penelitian ini melalui; observasi, wawancara, studi dokumentasi dan studi pustaka.

\section{Teknik Analisis Data}

Teknik analisis data adalah cara menganalisis data yang diperoleh dari penelitian untuk mengambil kesimpulan hasil penelitian. Proses analisis data dengan menelah seluruh data yang tersedia dari berbagai sumber yang telah diperoleh dari penelitian di lapangan, yaitu dari wawancara pengamatan yang sudah dituliskan dalam catatan lapangan, dokumen pribadi, dokumen resmi, gambar, foto dan sebagainya (Moleong, 2000).

\section{HASIL DAN PEMBAHASAN}

\section{A. Meningkatkan pelayanan}

Dalam meningkatkan pelayanan pelaku usaha jasa sewa mobil, Rental Restu selalu menjaga kondisi mobil yang akan disewakan, agar pelanggan selalu merasa puas dan nyaman dengan apa yang diberikan oleh pelaku usaha jasa sewa mobil Rental Restu. Disamping menjaga kondisi mobil, pelaku usaha jasa sewa mobil Rental Restu juga harus menjaga perilaku dalam memberikan pelayanan yang baik terhadap pelanggan agar pelanggan merasa dihargai dan akan timbul kepuasan karena pelayanan yang diberikan sangat baik oleh pelaku usaha jasa sewa mobil Rental Restu.

Menurut bapak ivan (salah satu pelanggan) pelayanan yang diberikan dari Rental Restu kepada saya cukup memuaskan karena cara berkomunikasi sangat baik dan 
informasi yang mereka berikan juga dapat saya terima dengan jelas. Selain itu kondisi fisik mobil juga sangat baik dan itu memuaskan saya sebagai pelanggan. Tentunya ini menjadi nilai baik bagi Rental Restu karena dari segi pelayanan mereka sangatlah memperhatikan. Saya juga sudah sering menyewa jasa transportasi (mobil) disini (rental restu) yaaa karena itu tadi, pelayanan yang diberikan sangat memuaskan bagi saya. Saya tidak tau dengan konsumen/pelanggan lainnya, karena masing-masing orang punya tingkat kepuasan berbeda-beda.

Menurut Siparuan (2000) pelayanan adalah usaha pemberian bantuan atau pertolongan kepada orang lain. Baik berupa materi maupun non materi agar orang itu dapat mengatasi masalahnya sendiri. Lanjut Monir (2005) menjelaskan bahwa pelayanan adalah proses pemenuhan kebutuhan melalui usaha orang lain secara langsung.

\section{B. Manajemen rental mobil}

\section{Manajemen keuangan}

Manajemen keuangan rental mobil merupakan bagian paling intim jika berbicara bisnis rental mobil. Kesalahan manajemen keuangan menyebabkan bisnis anda akan tersendat dan mengalami kebangkrutan. Keuangan merupakan dasar penting menjadi tolak ukur sukses bisnis rental mobil. Karena pada dasarnya bisnis ini adalah bisnis operasional, sudah pasti tentu menggunakan anggaran untuk menjalankannya. Uang masuk dan keluar dalam bisnis rental mobil harus rinci sedetail mungkin, hal ini agar menghindari minus pada saat penghitungan akhir bulan. Caranya bagaimana mengelola keuangan, mudah saja, anda harus mencatat setiap detail uang masuk yang berhubungan dengan rental atau penyewaan mobil. Pencatatan detail anggaran yang digunakan untuk rental mobil. Baik itu anggaran terduga atau anggaran rutin maupun anggaran tidak terduga alias mendadak. Dengan pencatatan tersebut anda dapat melakukan evaluasi setiap periode, misalkan saja perbulan. Dengan evaluasi tersebut anda akan mengetahui pola aliran keuangan yang ada dalam bisnis rental mobil. Dengan demikian anda akan dapat melakukan strategi dan taktik agar bisnis rental mendapat profit dan laba banyak secara maksimal. Dengan demikian omset akan dapat ditarget dengan sukses untuk jangka waktu berikutnya.

2. Manajemen armada/mobil

Manajemen mobil sangat penting dilakukan. Alasannya adalah karena armada atau mobil adalah bahan bakar utama bisnis rental mobil. Jika armada atau mobil tidak ada maka ini bukan menjadi bisnis rental mobil. Mobil adalah nadi dari bisnis ini. Pentingnya manajemen mobil hubungannya sangat erat dengan pelayanan terhadap konsumen atau pelanggan rental mobil. Coba saja bayangkan jika armada atau mobil yang akan anda sewakan dalam perusahaan rental mobil anda sudah mau rusak gampang mogok, pasti pelanggan akan hanya sekali saja menggunakan jasa penyewaan anda. Lain jika mobil yang anda tawarkan kepada pelanggan, dalam keadaan baik, sehat, rapih dan nyaman, ini akan lebih memanjakan konsumen anda. Pelayanan yang baik ini membuat bisnis rental mobil anda mempunyai posisi penting di hati pelanggan. Dan bersiap saja jasa anda akan dipakai lagi lain waktu atau bahkan bisnis anda dipromosikan sebagai jasa terbaik di hati pelanggan.

3. Manajemen pengemudi / sopir

Pengemudi atau sopir adalah adalah bagian dari bisnis anda yang tidak boleh 
diremehkan. Jika memang penyewaan atau rental mobil menggunakan sopir, anad harus benar-benar mencari sopir yang memang benar loyal dengan anda. Jangan sampai kesalahan anda dalam mencari sopir justru menghancurkan bisnis anda, atau istilahnya main belakang. Banyak kejadian ditempat lain, sparepart mobil banyak yang hilang karena dijual satu persatu oleh sopir yang nakal, atau bahkan hanya ditukar dengan sparepart bekas. Jika begini konsumen dan anda juga yang akan dirugikan nantinya. Maka dari itu seleksilah sopir yang benarbenar terbaik dan terpercaya.

\section{Manajemen administrasi}

Administrasi lebih tepatnya adalah pembukuan. Banyak sekali pembukuan yang disepelekan dalam bisnis rental mobil. Misalkan saja pencatatan dana tidak terduga serta pengeluaran-pengeluaran yang diluar. prediksi. Jika ini terjadi maka anda akan kesulitan melakukan evaluasi jika terjadi banyak kejanggalan pada kegiatan rental mobil. Salah satu contohnya jika armada yang digunakan ada lebih dari satu atau banyak, sudah menjadi barang tentu anda harus detail dan teliti mencatat aktivitas setiap armada serta pengemudi yang membawanya. Dengan demikian anda akan dapat dengan mudah melakukan pengambilan keputusan jika terdapat masalah pada salah satu armadanya. Untuk memudahkan itu kami mengembangkan softare rental mobil yang baik untuk membantu bisnis anda.

\section{Manajemen pelanggan}

Pelanggan adalah detak jantung bisnis anda, mungkin kedengarannya sedikit lebay istilahnya. Tapi tanpa konsumen bisnis anda bukan apa-apa. Manajemen konsumen adalah melakukan pendataan konsumen agar lebih terperincih, tujuannya adalah untuk memudahkan memberikan pelayanan kepada konsumen. Pelayanan tersebut misalkan saja memberikan promo pada hari tertentu, promo pada masa liburan, diskon paket liburan dan banyak strategi lainnya yang dapat dilakukan untuk menjalin kedekatan dengan konsumen rental mobil. Pencatatan pelanggan dapat denga mudah dengan software yang kami kembangkan, anda tidak perlu lagi secara manual melakukan beberapa poin manajemen ini, cukup klik dan klik. Data yang dikelola misalnya data pelanggan nama pelanggan, No telepon atau hp, alamat serta beberapa data penting lainnya.

\section{KESIMPULAN}

Dari hasil perilaku dalam pelayanan di Rental Restu maka dapat diambil kesimpulan bahwa :

1. Pelayanan terhadap pelanggan di rental restu sangat berpengaruh pada kepuasan pelanggan/konsumen.

2. Berperilaku baik akan menimbulkan kepuasan terhadap pelanggan dan pelaku usaha rental mobil khususnya rental restu, dan dapat membuat penghasilan semakin meningkat (keuntungan yang besar).

3. Dengan adanya aturan sewa menyewa mobil akan menjadi usaha jasa rental mobil di kabupaten biak numfor lebih dipercaya masyarakat karena dianggap resmi dan bertanggung jawab.

\section{DAFTAR PUSTAKA}

Ari Prasetio, "Pengaruh kualitas pelayanan dan harga Terhadap kepuasan Pelanggan”, Jurnal manajemen Vol. 1 No.4, 2012 
Adhikarini. 2003. Analisis tingkat kualitas jasa pelayanan terhadap kepuasan pelanggan, surakarta : UNS

Jean Harvey, "Service quality: a tutorial", Journal of Operations Management, 1998, No.16

Kolter, Phillip. 2002. Manajemen Pemasaran di Indonesia : Analisis, Perencanaan, Implementasi dan Pengendalian. Salemba Empat. Jakarta.

Kamaludin, Rustian. 1986. Ekonomi Transportasi. Jakarta. Ghalia Indonesia

Swastha, Basu. 2000. Azas-azas Marketing. Liberty. Yogyakarta.
Salim, A. Abas. 1998. Manajemen Transportasi, Edisi Pertama. Jakarta rajawali Press.

Tjiptono, Fandy. 2001. Strategi Pemasaran. Edisi pertama. Andi Ofset.Yogyakarta.

Tjiptono, Fandy, (1995). Strategi. Pemasaran. Yogyakarta : Andi

Umar, Husein, (2003). Metode Riset. Perilaku Konsumen Jasa. Jakarta: Ghalia Indonesia. 